Cite this article as: Malca, O., Peña-Vinces, J. \& Acedo, F. (2019) Export promotion programmes as export performance catalysts for SMEs: insights from an emerging economy. Small Bus Econ

(2019).https://doi.org/10.1007/s11187-019-00185-2.

\title{
Export promotion programmes as export performance catalysts for SMEs: Insights from an emerging economy
}

\author{
Oscar Malca (Corresponding author) \\ Universidad del Pacífico \\ Av. Salaverry 2020, Jesús María 15072, Perú \\ EMAIL: malcaoe@up.edu.pe \\ Jesus Peña-Vinces \\ Universidad de Sevilla \\ Av. Ramón y Cajal nº 1 41018, Sevilla, Spain \\ EMAIL: jesuspvinces@us.es \\ Phone: +34954 554438 \\ Acedo Francisco, \\ Universidad de Sevilla \\ Av. Ramón y Cajal no 1 41018, Sevilla, Spain \\ EMAIL: fjacedo@us.es
}

\begin{abstract}
The purpose of the study is to analyse the joint impact of external factors of small and medium-sized enterprises (SMEs), such as export promotion programmes (EPPs), which encompass trade mobility-, information-, education-, and trainingrelated programmes, and internal factors of SMEs, which encompass export-related resources, preceding-year export performance, and its impact on current-period export performance. The study tests their relationship with structural equation modelling using a random sample of 95 exporting SMEs in an emerging economy, Peru. The results indicate that experiential knowledge provided by trade mobility-related programmes and export performance of the preceding year positively influence the resources of SMEs oriented towards export activity as well as current export performance. Moreover, the results highlight the need to review the efficacy and design of EPPs, acknowledging the available resources of SMEs as well as the internationalisation theories of the firm, in order to enhance their influence on the international development and export performance of SMEs. Finally, the study has extended the knowledge about emerging economies by showing the role EPPs play in SMEs' export performance.
\end{abstract}

Keywords: SMEs, Export Promotion Programmes, organisational resources, export performance, structural equation models, Peru

JEL codes $\mathrm{F} 23 \cdot \mathrm{L} 38 \cdot \mathrm{M} 16$

\section{Acknowledgements}

We would like to thank Carlos Carrillo C. and Jean Pierre Bolaños for their support in the development of this study. Also, special thanks to the guest editors of this special issue, Alain Fayolle, Francisco Liñán and Justin Paul and the two anonymous reviewers who made helpful and valuable comments to greatly improve the quality this paper.

Conflict of Interest: The authors declare that they have no conflict of interest. 
Cite this article as: Malca, O., Peña-Vinces, J. \& Acedo, F. (2019) Export promotion programmes as export performance catalysts for SMEs: insights from an emerging economy. Small Bus Econ (2019).https://doi.org/10.1007/s11187-019-00185-2.

\section{$1 \quad$ Introduction}

The evolution of the internationalisation process of small and medium-sized enterprises (SMEs) often begins with export strategies, which can be explained by diverse theories such as international new ventures or born global paradigm (Oviatt and McDougall 1997; Paul and Gupta 2014) and the internationalisation process model (Andersen 1993; Johanson and Vahlne 1977; Paul, Parthasarathy and Gupta 2017). According to these theories, SMEs must commit their resources in order to undertake activities that lead to exporting and must overcome different export barriers. However, many firms are not able to achieve their potential or are just able to identify the existing opportunities (Freixanet 2010; Hessels and van Stel 2011). Thus, it is of vital importance for SMEs to study the factors that might condition their export performance ( $\mathrm{Lu}$ and Beamish 2001; Paul, Parthasarathyand Gupta 2017).

Although numerous studies have considered the determinants of export performance (see Sousa et al. (2008), among other reviews) and, particularly, the effect of export promotion on it (Li, Vertinsky and Zhang 2013; Leonidou, Palihawadana and Theodosiou 2011), most of them have assumed a direct effect on such performance. However, the performance obtained by each firm is just the result of the decisions made, and the export promotion programmes (EPPs) used are conditionants of such decisions (Leonidou, Palihawadana and Theodosiou 2011).

SMEs face many challenges on their way towards foreign markets, such as a lack of knowledge and credibility in comparison with domestic firms, scarcity of resources available for export activities (Paul, Parthasarathy and Gupta 2017), the need to rely on specialised information for decision making (Nalcacia and Yagcib 2014), and the psychic distance barrier in order to identify and exploit opportunities in international markets (Oviatt and McDougall 2005). Therefore, SMEs need to develop resources and capabilities with the purpose of overcoming these barriers and expanding their international presence (Oviatt and McDougall 2005). When this reality is analysed from a developing-country perspective, this lack of resources becomes a major issue.

Moreover, at the country level, exports are considered a source of competitiveness, employment creation, and tax revenue, among others, and thus governments commission trade promotion organisations (TPOs) to assist SMEs in minimising the risks associated with international activities and to increase their profitability (Kotabe and Czinkota 1992).

TPOs design and manage EPPs, whose main objectives are to foster a proactive attitude towards growth opportunities in foreign markets; create a network of contacts; provide information on competition and the gap between market requirements and firm capabilities (Freixanet 2012); minimise any negative perceptions related to higher costs in the short run, perceived risk level, and complexity of export activities (Leonidou, Katsikeas and Piercy 1998; Spence 2003); and promote the export venture and assist the internationalisation process of SMEs (Gençtürk and Kotabe 2001). Consequently, EPPs are designed to interact with the SMEs' organisational resources in order to attain a higher level of export performance (Fischer and Reuber 2003; Hultman, Katsikeas and Robson, 2011; Lages, Jap and Griffith 2008). For these reasons, studying the effect of EPPs on the export performance of SMEs is relevant, given the potential to improve their design, adaptation, and efficacy, as well as increase their credibility with the business community and reveal their impact on the internal factors of SMEs (Freixanet 2012). 
Cite this article as: Malca, O., Peña-Vinces, J. \& Acedo, F. (2019) Export promotion programmes as export performance catalysts for SMEs: insights from an emerging economy. Small Bus Econ (2019).https://doi.org/10.1007/s11187-019-00185-2.

With regard to the impact that EPPs exert on the organisational resources of the firm and, consequently, on its export performance, Lages and Montgomery (2005) argue that it is necessary to broaden the research, as many firms may be reluctant or unprepared to increase their international commitment, making it necessary to deepen the understanding of how promotion affects export performance. This need for research can be observed in the low degree of consensus regarding these variables in the literature, which shows positive and significant relationships (e.g., Broocks and Van Biesebroeck 2017; Weaver et al. 1998), a lack of significance (e.g., Francis and Collins-Dodd 2004; Wang et al. 2017), and mixed results (e.g., Gençtürk and Kotabe 2001; Van Biesebroeck et al. 2015).

Various research studies that examine export performance highlight the insufficiency and inconsistency in regards to the variables analysed and their findings, which are limited to the internal factors of the firm (Aaby and Slater 1989; Chen, Sousa and He 2016; Ruppenthal and Bausch 2009; Wheeler, Ibeh and Dimitratos 2008; Zou and Stan 1998). Furthermore, they also indicate that it is fundamental to expand the number of current models that explain this phenomenon (Leonidou, Katsikeas and Samiee 2002; Paul and Dikova 2016; Zou and Stan 1998), considering the joint impact between the external and internal variables of the firm on export performance and recognising its multidimensional nature (Cavusgil and Zou 1994; Freixanet 2012; Wheeler et al. 2008). Additionally, regarding the external impact exerted on export performance, previous studies are scarce, and the results lack consistency (Losada-Pérez, Ruzo-Sanmartín, Barreiro-Fernández and Navarro-García 2007; Ruppenthal and Bausch 2009; Zou and Stan 1998). In the same manner, there is a lack of research studies that focus on emerging economies, in particular, those of Africa and Latin America (LA) (Chen, Sousa and He 2016; Zou and Stan 1998). Likewise, most of these research studies have focused their analysis on MNEs, foreign subsidiaries, strategic business units, and organisations that exhibit a high degree of international experience mainly from industrialised economies (Coughlin and Cartwright 1987; Gençtürk and Kotabe 2001; Haddoud, Jones and Newbery 2017; Leonidou, Katsikeas and Coudounaris 2010).

The objective of the present study is to analyse the joint impact of EPPs on internal resources, an approach that has been limitedly used in the literature, and these, in turn, on the firm in export performance in an emerging economy, namely Peru (Aaby and Slater 1989; Madsen 1987; Ruppenthal and Bausch 2009; Shamsuddoha et al. 2009), for which an explanatory model of export performance on SMEs is developed and empirically tested. In this way, we respond to a suggestion by Leonidou et al. (2011) about the need to study these economic environments that present not only different economic ecosystems but also different requirements in order to promote and develop EPPs.

Concerning SMEs' country study (Peru) and in accordance with the Bloomberg (2018) Emerging Markets Scorecard 2018, Peru (ninth position) has been considered one of the most attractive emerging market economies (EME) in LA, thus having a better position than Brazil (19th position), the biggest economy in LA. Consequently, for the past decade, Peru has kept its status as an EME (Bloomberg 2018). Using SMEs based in Peru as a study sample might serve as a path for other LA economies (Ecuador, Colombia, and Chile, Bolivia) operating from a similar environment as Peru.

From an FDI perspective, as happens in many other LA economies, the Peruvian business environment is chaotic and problematic. Due to the high rate of informality of domestic firms (accounting for $72 \%$ of total businesses), firms do not have legal registration in the government, which is a serious problem when an entrepreneur wants to start a business. 
Cite this article as: Malca, O., Peña-Vinces, J. \& Acedo, F. (2019) Export promotion programmes as export performance catalysts for SMEs: insights from an emerging economy. Small Bus Econ (2019).https://doi.org/10.1007/s11187-019-00185-2.

Regarding the government and the policy currently in Peru, corruption has become a huge problem for the Peruvian economy as well as for many other LA economies (Colombia, Venezuela, Ecuador, etc.), causing an unfavourable environment for the stability of business in the region, since a change of government usually means an enormous change of rules of the game for domestic firms as well as. SMEs have more difficulties overcoming these abrupt changes. The level of insecurity on the streets is typical in Peru as in many other LA countries (Mexico, Colombia, Venezuela), with the kidnapping of entrepreneurs being common. The government has invested vast quantities of money to address this problem, but it persists. On the other side, in international business the level of physical infrastructure (airports, ports, commercial trains) is essential for trade in Peru (Castro et al. 2016); however, its level is very low compared to some other EMEs, like the Asiatic giant China.

Peru's international trade is characterised by the exporting of raw materials. In fact, the World Bank's (2018) statistics reveal that only around $15 \%$ of the total LA exports are high-technology exports. Therefore, Peruvian SMEs would have serious problems gaining a competitive advantage from innovation from their supply chains (Peña-Vinces et al. 2017). The above features described are also typical in many other LA economies; therefore, this is the kind of environment from which the Peruvian SMEs must compete abroad.

Firstly, this study highlights the need to focus on EPPs, the resources of SMEs, and their joint impact on export performance. Secondly, concerning the relevant literature, the study presents the theoretical framework of the model and the research hypotheses. Thirdly, the study describes the methodology of the research as well as a discussion of the results obtained. Finally, the study analyses the implications and recommendations for policy-makers and managers, and it acknowledges its limitations and provides further research directions.

\section{Conceptual Framework}

The literature suggests that the two more used theories in EEPs are the internationalisation theory (process or sequential approach to internationalisation) (Lim, Sharkey and Kim 1996; Singer and Czinkota 1994) and the resource-based view (RBV) (Francis and Collins-Dodd 2004; Gençtürk and Kotabe 2001; Seringhaus and Botschen 1991; Seringhaus and Rosson 1998; Spence 2003; Faroque and Takahashi 2015). The first approach is aimed at understanding how the different agencies and programmes help firms in their internationalisation process, passing from one stage to another, or increasing their commitment into the international markets. This approach assumes, in most cases, a direct effect of the EPPs on the evolution of the firm or studies the process by which firms decide to participate in the programmes. The second approach is firm-centred. Thus, Francis and Collins-Dodd (2004) pose that the objective of EEPs is to increase export performance by improving resources, capabilities, strategies, and competitiveness. Despite this assertion, many studies have also accepted a direct effect of EPPs on export performance.

The research studies reviewed highlight the need to continue further research on export performance, supplying empirical evidence from SMEs of emerging economies, such as Peru, through the interrelationship of factors outside and within the firm. To be precise, we assume that the performance achieved by each firm will be determined by the quality of its resources and decisions towards this goal. This takes us closer to one of the leading paradigms regarding internal factors, the RBV, 
Cite this article as: Malca, O., Peña-Vinces, J. \& Acedo, F. (2019) Export promotion programmes as export performance catalysts for SMEs: insights from an emerging economy. Small Bus Econ (2019).https://doi.org/10.1007/s11187-019-00185-2.

which holds that the growth of the firm is subject to its resources (Penrose 1959), which influence the firm's performance and competitive advantage in domestic and foreign markets (Barney 1991; Chen Sousa and He 2016; Kaleka 2002).

This approach was used by Dhanaraj and Beamish (2003) to explain export performance, and the authors studied how the different types of resources are linked to export performance. Later, and through the use of managerial, intellectual, production, and innovation resources, Leonidou et al. (2011) analysed the interrelationship of the export-related organisational resources of SMEs and their impact on export performance. In the same manner, the model incorporates the impact of the export performance of the preceding year on organisational resources as well as on the current period's export performance (Lages, Jap and Griffith 2008; Levinthal and March 1993). Most studies assume that the amount and types of resources associated with exporting condition the performance.

As previously mentioned, Francis and Collins-Dodd (2004) suggested the possibility that the action of the EPPs could modify the resources associated with export activities. The number of programmes existing worldwide is very diverse, so it is necessary to adapt them to the socio-economic environment analysed (Gillespie and Riddle 2004). Traditionally, EPPs have tried to interact with firms by stimulating export through different programmes, but the impact of EPPs has been seen further, as they are supposed to influence the export-related organisational resources and, through these, the export performance of SMEs (Leonidou, Palihawadana and Theodosiou 2011).

A review of the relevant literature highlights that export performance is defined as 'the outcome of a firm's activities in the export market' (Chen et al. 2016, p. 626). This phenomenon is commonly measured in the literature through three dimensions: a financial measurement (also called economic or objective), non-financial measures (non-economic or subjective), and composite scales, which combine the previous two (Cavusgil and Zou 1994; 2008; Zou and Stan 1998). As pointed out by Katsikeas et al. (1996), the use of objective indicators for export performance (e.g., market share, ROI, export value/volume) may present a bias due to the divergence in accountability practices among firms, their noncomparability across industries and product categories, and the difficulty of their disclosure in an emerging market context (Hult et al. 2008). Furthermore, they present a limitation in the measurement of export performance according to the behavioural theory of the firm paradigm, since the decision-making process is based upon the subjective evaluation of objective performance indicators (Cyert and March 1992). Given the presence of bounded rationality in the decisionmaking process, employment of heuristics and subjective interpretations of the 'objective' indicators are the drivers of organisational change (March and Sutton 1997). Thus, the perception of the performance of the firm is responsible for future decisions and corresponds to the concept of export performance in the literature (Aaby and Slater 1989; Buckley et al. 1990; Madsen 1989).

\subsection{Hypothesis}

EPPs have the objectives of assisting SMEs in overcoming market access, information, and operational barriers in foreign markets; competing in international markets (Freixanet 2012); fostering the process of experience and market knowledge acquisition; and increasing the level of commitment towards export activities and international expansion (Shamsuddoha, Yunus Ali and Ndubisi 2009; Singer and Czinkota 1994). This diversity of programmes has been commonly analysed by creating different groupings of programmes. Seringhaus and Rosson (1991), classified programmes as those oriented to 
needs, motivations, information, and operations. Calderón and Fayos (2004) only used motivations, information, and operations. Hence, EPPs rely on information-, education-, and training-related programmes as well as trade mobility activities regarding trade shows, trade missions, and support from trade offices in the foreign market (Leonidou, Palihawadana and Theodosiou 2011; Wilkinson and Brouthers 2000). Thus, EPPs affect the level of commitment and development of export-related resources of SMEs (Shamsuddoha, Yunus Ali and Ndubisi 2009; Wang, Chen, Wang and Li 2017). Based on the above, the following hypotheses are proposed:

H1. EPPS' information-, education-, and training-related programmes positively influence the export-related organisational resources of SMEs.

H2. EPPS' trade mobility-related programmes positively influence the export-related organisational resources of SMEs.

Business activity is usually evaluated by how performance outcomes fulfil performance goals (Lant 1992; Lant, Milliken and Batra 1992). If these goals are not reached, this will surely influence managerial action and provoke strategic change (Lant and Mezias 1992; Levitt and March 1988). Taking this into account, current-period export performance is influenced by the export performance of the preceding year as well as the organisational resources committed to the export venture (Lages, Jap and Griffith 2008; Luo and Peng 1999). Consequently, the export performance of the preceding year is considered internal to the firm, as it conditions the actions taken by the firm, reinforcing those that have had a positive impact (i.e., 'path-dependency') (Cyert and March 1992). In this manner, the results obtained from previous years are key to organisational learning (Lages, Jap and Griffith 2008). When positive, they reinforce the firm's previous strategic export decisions as well as the mechanisms in which the SME acquires foreign market knowledge (Navarro, Acedo, Losada and Ruzo 2011); when negative, they will motivate the firm to redirect its export strategy (Lages and Montgomery 2005). Thus, the positive export performance of previous periods facilitates the access to resources and information geared towards sustaining and promoting higher levels of export performance in the future (Lages, Jap and Griffith 2008). Besides, the positive results will reinforce the strategy of the firm and will surely increase its commitment of resources. Therefore, the following hypothesis is proposed:

H3. A high export performance of the preceding year will present a positive effect on the export-related organisational resources of SMEs.

Organisational learning identifies past experiences as building blocks for future strategic decision-making (Lages, Jap and Griffith 2008; Levinthal and March 1993; March and Sutton 1997). Accordingly, firms adjust their marketing and export strategies based on the lessons learned from previous export performance results (Cyert and March 1992; Helfat 1994; Hultman, Katsikeas and Robson 2011). Thus, firms that present a strong relationship between previously achieved export performance and current export performance are less prone to export strategy reorientation (March and Sutton, 1997) due to change resistance arising from firms' internal and external agents and the perceived risk of an adaptive behaviour (Greeve 1998). In this sense, the export decision-maker evaluates the effectiveness of previous routines against their perceived performance to assess their suitability, reflecting the path-dependent nature of the decision-making process in their export venture (Johanson and Vahlne 1977). As a result, firms obtain inertial results given that they professionalise the organisational practices that were perceived to lead to higher levels of export performance in the preceding year, 
Cite this article as: Malca, O., Peña-Vinces, J. \& Acedo, F. (2019) Export promotion programmes as export performance catalysts for SMEs: insights from an emerging economy. Small Bus Econ (2019).https://doi.org/10.1007/s11187-019-00185-2.

revealing the path-dependent nature of this process (March and Sutton 1997). Thus, assessment of the previous year's export performance delimits the practices and procedures that are maintained and produces a feedback loop that affects the degree to which the firm is able to attain its export objectives and assess them regarding past results (Cyert and March 1992; Lages, Jap and Griffith 2008). Based on the aforementioned literature, the following hypothesis is presented:

H4. Export performance of the preceding year positively influences current export performance.

According to the RBV, the organisational resources of the firm have a positive impact on the firm's performance (Aaby and Slater 1989; Acedo, Barroso and Galan 2006; Piercy, Kaleka and Katsikeas 1998; Zou and Stan 1998). These organisational resources are the tangible assets of the firm, which allow them to possess a fixed capacity in the short run (Ruppenthal and Bausch 2009; Wernerfelt 1984), and the intangible assets of the firm, which include intellectual property, such as brands, capabilities, processes, managerial qualities, information, and knowledge. These assets sustain competitive advantage in the long run (Conner and Prahalad 1996; Hessels and van Stel 2011). The export-related organisational resources enable the firm to exploit opportunities in the international market and mitigate external threats (Cavusgil and Zou 1994; Leonidou, Palihawadana and Theodosiou 2011; Wheeler, Ibeh and Dimitratos 2008); they are difficult to imitate in the short-medium term and have the characteristic of being scarce among firms of the same industry (Barney 1991). In this manner, firms elaborate export plans and strategies that allow them to have above-average export performance levels, based on unique resources that are difficult to imitate (Hult, Ketchen and Slater 2005; Morgan, Vorhies and Schlegelmilch 2006). Consequently, adequate organisational resources oriented to the development of the export market enable a higher level of performance (Dhanaraj and Beamish 2003; Kaleka 2002; Wheeler, Ibeh and Dimitratos 2008). Thus, the following hypothesis is developed:

H5. The export-related organisational resources of the firm positively influence current-period export performance.

A synthesis of the concepts and hypotheses proposed, as well as the impact on export performance, is illustrated in the following path model:

Fig. 1 Conceptual model and research hypotheses

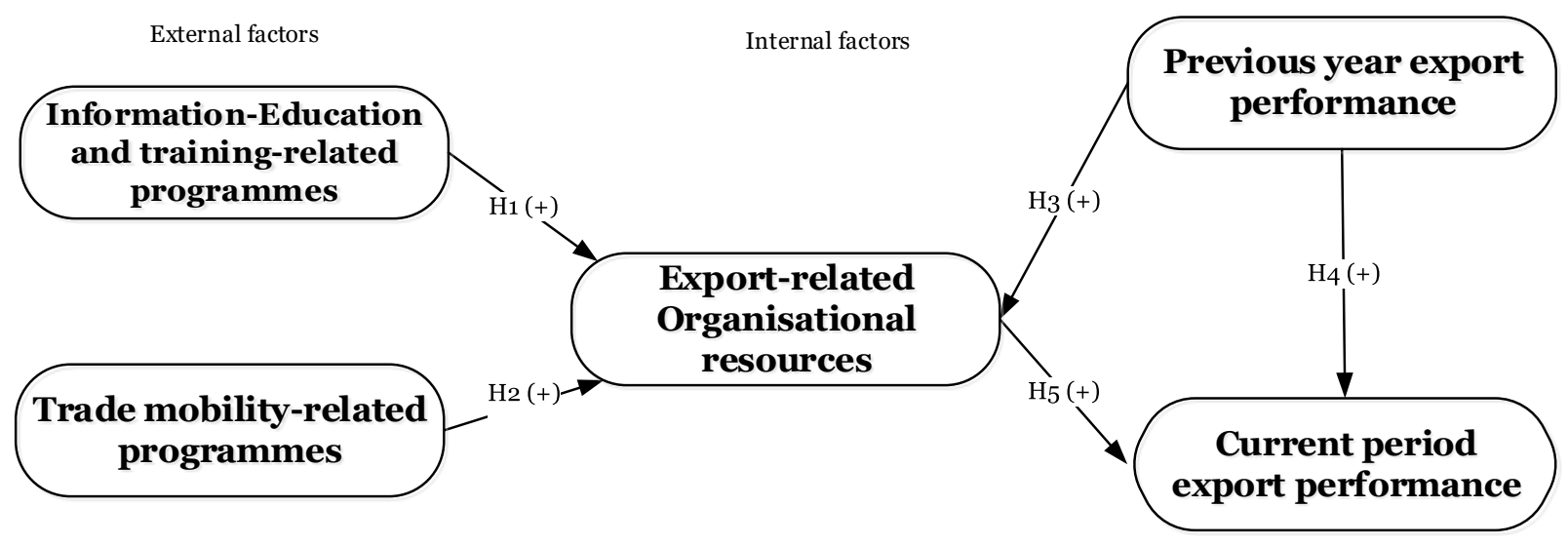


Cite this article as: Malca, O., Peña-Vinces, J. \& Acedo, F. (2019) Export promotion programmes as export performance catalysts for SMEs: insights from an emerging economy. Small Bus Econ (2019).https://doi.org/10.1007/s11187-019-00185-2.

\section{Methodology}

Due to the multivariate nature of the variables that affect export performance (Chen, Sousa and He 2016), the study adopted a cross-sectional and causal approach (Hair, Black, Babin and Anderson 2014). Regarding the study's sample, we must explain how to characterise an emerging market's SME, given that most researchers suggest using the European Commission's (2005) criteria, which have established the staff headcount as an obligatory norm to categorise an SME (i.e., small enterprises $[\mathrm{SE}] \leq 50$ employees; medium-sized enterprises $[\mathrm{ME}] \leq 250$ employees). Nevertheless, this institution also suggests that an enterprise may elect to fit on either the turnover (i.e., $\mathrm{SE} \leq 10 €$ million; $\mathrm{ME} \leq 50 €$ million) or the balance sheet total ceiling. Furthermore, SMEs do not need to meet both criteria, since they might exceed one of them without losing their status (European Commission 2005). However, in the emerging market context (Peru), a staff headcount cannot be applied, as the government of Peru has established the turnover as a unique criterion of classification of an SME (Agencia de Promoción de la Inversión Privada - Perú - PROINVERSION 2013). Therefore, we only used turnover as a criterion to categorise our SMEs. In fact, in the SME context, empirical research carried out in Peru has used turnover as a unique criterion of categorisation (see, e.g., Peña-Vinces et al. 2017).

It is crucial to highlight that in the context of developing countries, the appropriateness of SMEs' turnover as a sole criterion makes sense, given that inclusion of the headcount would not be accurate, as the Peruvian labour market is characterised by a high rate of temporality (seasonal workers) and by labour-intensive sectors, such as the textile and agribusiness industries, where firms usually hire workers on a campaign basis. Therefore, seasonal workers do not have stable contracts as happens in developed countries.

Thus, the sample characteristics (SMEs), presented in Table 1, reveal this issue, given that around 20\% of SMEs have 500 or more employees, which, in turn, corresponds to the agribusiness, textile, and clothing sectors, which are characterised by the aforementioned labour intensity and thus require seasonal workers due to the lack of technology in their production processes, which is typical in emerging economies.

Regarding data collection, the pre-tests of the questionnaire were assessed in workshops with high-ranking officers from the Peruvian TPO, representatives of several industries from the Lima Chamber of Commerce and Exporters' Association of Peru, and three managers of exporting SMEs graduated from one of the most prestigious Peruvian universities (Universidad del Pacífico) regarding training of entrepreneurs. After the questionnaires were evaluated for their reliability and validity during the pre-test, the study proceeded to the second process, data collection. The study took into account the low response rate in the context of emerging economies (e.g., Peña-Vinces et al. 2017) and took measures to avoid potential bias in the employment of mono-methods (Chang, van Witteloostuijn and Eden 2010; Doty and Glick 1998; Podsakoff, MacKenzie, Lee and Podsakoff 2003). We followed a staged strategy used in previous studies (Harzing 1997; Harzing, Reiche and Pudelko 2013). First, we held meetings with government officials from the Peruvian TPO (PROMPERU by its Spanish acronym) in order to identify the universe of exporting SMEs that currently are users of various EPPs. We then corroborated the database with INFOTRADE, a government-led exports-imports database that employs official data from the National Taxes Administration (SUNAT by its Spanish acronym). 
Cite this article as: Malca, O., Peña-Vinces, J. \& Acedo, F. (2019) Export promotion programmes as export performance catalysts for SMEs: insights from an emerging economy. Small Bus Econ (2019).https://doi.org/10.1007/s11187-019-00185-2.

After validating the information, the study identified 4,000 exporting SMEs, of which only 1,500 exported continuously for at least three years. Then, the study randomly selected 400 exporting SMEs from the 1,500 sampling framework, with a $4.2 \%$ sample error, given a 95\% confidence interval. The study identified the managers responsible for the export activity and sent a screening email to validate the sampled firms. After the screening email, we sent a second email to the managers (a total of 400 firms) that guaranteed that the study would be aggregated and no firm would be identified separately. Subsequently, we contacted the 400 exporting SMEs by telephone to inform them about the importance of our study. Lastly, we visited some manufacturers to present the study and to have an informal interview with the managers to talk about the transcendence and importance of this study to the region. This last step was necessary because many managers were afraid to disclose sensitive information.

Moreover, in this sense, the research team held meetings with the managers of the sampled firms to apply the questionnaire, since most firms preferred to hand in the information in a physical format, rather than by telephone or email. This is a consistent behaviour due to the levels of insecurity that exist in LA, where company information is seldom disclosed, especially for research studies. Finally, following the data collection, the study obtained 95 valid questionnaires, resulting in a response rate of $23.75 \%$.

The study retrieved 60 responses from interviews and 35 responses via email. Since two data collection methods were employed, the study tested for differences in firm-level characteristics and measurement scale scores via t-tests and the $\mathrm{U}$ Mann-Whitney test, as a non-parametric analogous method. Neither test revealed statistically significant differences between the two methods, thus failing to find evidence for bias in the responses attributable to the data collection methods employed.

The quantity of questionnaires obtained is consistent with previous studies in business research, which usually range between 52 and 285, as well as with the insufficient number of research studies executed on export performance of firms from emerging economies (Chen, Sousa and He 2016). The characteristics of the SMEs sampled are presented in Table 1.

Table 1 Characteristics of the sample at firm and respondent levels 
Cite this article as: Malca, O., Peña-Vinces, J. \& Acedo, F. (2019) Export promotion programmes as export performance catalysts for SMEs: insights from an emerging economy. Small Bus Econ (2019).https://doi.org/10.1007/s11187-019-00185-2.

\begin{tabular}{|c|c|c|c|}
\hline & $\underline{\%}$ & & $\underline{\%}$ \\
\hline \multicolumn{4}{|l|}{ Exporting firm } \\
\hline \multicolumn{2}{|l|}{ Firm size (headcount) } & \multicolumn{2}{|l|}{ Firm age (years) } \\
\hline$<10$ & $19.10 \%$ & $<10$ & $26.60 \%$ \\
\hline $10-49$ & $34.00 \%$ & $10-19$ & $39.40 \%$ \\
\hline $50-99$ & $7.40 \%$ & $20-29$ & $9.60 \%$ \\
\hline $100-500$ & $19.10 \%$ & $30-39$ & $6.40 \%$ \\
\hline$\geq 500$ & $20.20 \%$ & $\geq 40$ & $18.10 \%$ \\
\hline \multicolumn{2}{|l|}{ Industry } & \multicolumn{2}{|c|}{ International experience (years) } \\
\hline Agribusiness & $60.60 \%$ & $<5$ & $11.70 \%$ \\
\hline Manufacturing & $13.80 \%$ & $5-9$ & $29.80 \%$ \\
\hline Textile and clothing & $13.80 \%$ & $10-14$ & $24.50 \%$ \\
\hline Fishing & $4.30 \%$ & $15-19$ & $12.80 \%$ \\
\hline Handicraft & $2.10 \%$ & $\geq 20$ & $21.30 \%$ \\
\hline Software & $2.10 \%$ & \multicolumn{2}{|c|}{ Export value of total sales } \\
\hline Mining & $1.10 \%$ & $<20$ & $10.60 \%$ \\
\hline Metallurgy & $1.10 \%$ & $20-39$ & $6.40 \%$ \\
\hline Others & $1.10 \%$ & $40-59$ & $7.40 \%$ \\
\hline Export value (€ Mill.) & & $60-79$ & $10.60 \%$ \\
\hline$<1$ & $24.20 \%$ & $\geq 80$ & $64.90 \%$ \\
\hline $1-10$ & $53.80 \%$ & & \\
\hline $10-49$ & $22.00 \%$ & & \\
\hline \multicolumn{4}{|l|}{ Respondent: } \\
\hline Age (years) & & Education & \\
\hline$<25$ & $1.10 \%$ & $M B A$ & $2.20 \%$ \\
\hline $25-34$ & $15.60 \%$ & Graduate studies & $14.00 \%$ \\
\hline $35-44$ & $34.40 \%$ & Undergraduate stud & $79.60 \%$ \\
\hline $45-54$ & $26.70 \%$ & Incomplete undergr & $4.30 \%$ \\
\hline$\geq 55$ & $22.20 \%$ & & \\
\hline
\end{tabular}

\subsection{Scales and measurement}

The concepts implemented in the conceptual model are measured through the use of composite variables, given that they facilitate the empirical testing of hypotheses that incorporate relationships between conceptual variables defined by their attributes (Sarstedt, Hair, Ringle, Thiele and Gudergan 2016). Therefore, scales from previous studies were employed in order to operationalise the external and internal factors analysed (Navarro, Acedo, Losada and Ruzo 2011). Regarding the external factors, the study assessed the utility of EPPs as an external resource to the firm (Shamsuddoha, Yunus Ali and Ndubisi 2009; Leonidou, Palihawadana and Theodosiou 2011). Whereas, the study evaluated the trade mobility-, information-, education-, and training-related dimensions using the scales of Leonidou, Palihawadana, and Theodosiou (2011) to provide an objective assessment of their adoption and use in the company. Regarding the internal variables, the organisational resources were evaluated according to three dimensions: managerial, intellectual, and production and innovation resources (Kaleka 2002; Leonidou, Palihawadana and Theodosiou 2011). Furthermore, the study employed subjective scales for the measurement of the preceding year and current-period export performance, given that objective measurements are not directly comparable across industries; they are influenced by accountability practices and the limitation of their disclosure in the context of analysis (Hult et al. 2008). Since 'management action is driven by perceptions of company performance rather than by objective calibration of its performance characteristics' (Katsikeas et al. 1996, p. 11), the export performance is measured through two subjective dimensions - the degree of export objectives achievement and the degree of overall satisfaction with the export performance - adopted from Lages et al. (2008). Likewise, following Peña-Vinces et al.'s (2017) recommendations, we used four control variables (see Table 5). These authors established that the use of control variables must be compulsory when a researcher is evaluating a firm's performance, as it is conditioned for multiple factors (e.g., sector and size). The items used in the questionnaire and their source are presented in Appendix A. 
Cite this article as: Malca, O., Peña-Vinces, J. \& Acedo, F. (2019) Export promotion programmes as export performance catalysts for SMEs: insights from an emerging economy. Small Bus Econ (2019).https://doi.org/10.1007/s11187-019-00185-2.

\subsection{Data analysis strategy}

To empirically test the research hypotheses, the study followed the recommendation of Zou and Stan (1998) and Chen et al. (2016) on the use of structural equation modelling. Accordingly, variance-based partial least squares structural equation modelling (PLS-SEM) techniques were employed, regarding the need to measure the manager's perception of the firm's internal and external factors. PLS-SEM was developed as a prediction-exploration alternative structural equation modelling technique that focuses on explaining the variance in the endogenous variables (Hair et al. 2017; Jöreskog and Wold 1982). PLS-SEM relaxes the required assumptions on the variables' distribution, differences in scale measurement, and sample size requirements (Reinartz, Haenlein and Henseler 2009). In the present study, the sample size exceeds the minimum requirements according to the number of relationships tested, the number of control variables, and the complexity of the structural model (Hair, Ringle and Sarstedt, 2013). SmartPLS 3.2.7 was used for the calculations of the PLS-SEM (Ringle, Wende and Becker 2015). Reflective-reflective second-order variables were used in the measurement model due to the hierarchy of the measurement scales (Hair et al. 2017).

\section{Results}

The structural model exhibits convergent validity, through the analysis of composite reliability (CR) values (all values $\geq$ 0.7 ) and factor loadings (all loadings $\geq 0.707$ ) (see Appendix A), and discriminant validity, through the Fornell-Larcker criterion, the heterotrait-monotrait correlations ratio test, and the cross-loadings criterion (Hair et al. 2017), which are presented in Tables 2, 3, and 4, respectively. Table 5 presents the empirical t-test results for the path coefficients, obtained through 5,000 bootstrap subsamples, and Figure 2 shows the statistical significance of the path coefficients, as well as the adjusted R2 of the endogenous variables and the control variables.

\begin{tabular}{|c|c|c|c|c|c|c|c|c|c|c|c|c|}
\hline \multirow{2}{*}{\multicolumn{3}{|c|}{ fame a Discriminta }} & \multicolumn{3}{|c|}{ (A) } & \multicolumn{2}{|c|}{ (B) } & \multicolumn{3}{|c|}{ (C) } & \multicolumn{2}{|c|}{ (D) } \\
\hline & & & 1.- & 2.- & 3.- & 4.- & 5.- & 6.- & 7.- & 8.- & 9.- & 10.- \\
\hline \multirow{3}{*}{$\begin{array}{l}\text { (A) Export } \\
\text { promotion } \\
\text { programmes }\end{array}$} & 1.- & $\begin{array}{l}\text { Information-related } \\
\text { programmes }\end{array}$ & 0.87 & & & & & & & & & \\
\hline & 2.- & $\begin{array}{l}\text { Education- and training- } \\
\text { related programmes }\end{array}$ & 0.82 & 0.85 & & & & & & & & \\
\hline & 3.- & $\begin{array}{l}\text { Trade mobility-related } \\
\text { programmes }\end{array}$ & 0.64 & 0.67 & 0.90 & & & & & & & \\
\hline \multirow{2}{*}{$\begin{array}{l}\text { (B) Preceding } \\
\text { year's exp. } \\
\text { performance }\end{array}$} & 4.- & $\begin{array}{l}\text { Performance achievement in } \\
\text { preceding year }\end{array}$ & -0.11 & -0.11 & -0.03 & 0.90 & & & & & & \\
\hline & 5.- & $\begin{array}{l}\text { Satisfaction with preceding } \\
\text { year's performance }\end{array}$ & -0.02 & -0.08 & 0.00 & 0.80 & 0.90 & & & & & \\
\hline \multirow{3}{*}{$\begin{array}{l}\text { (C) Export- } \\
\text { related } \\
\text { organisational } \\
\text { resources }\end{array}$} & 6.- & Managerial resources & 0.00 & -0.04 & 0.20 & 0.26 & 0.36 & 0.78 & & & & \\
\hline & 7.- & $\begin{array}{l}\text { Production and research-and- } \\
\text { development (R\&D) resources }\end{array}$ & -0.08 & -0.13 & 0.03 & 0.30 & 0.38 & 0.70 & 0.80 & & & \\
\hline & 8.- & Intellectual resources & -0.07 & -0.07 & 0.08 & 0.28 & 0.29 & 0.46 & 0.68 & 0.81 & & \\
\hline \multirow{2}{*}{$\begin{array}{l}\text { (D) Current } \\
\text { export } \\
\text { performance } \\
\text { improvement }\end{array}$} & 9.- & $\begin{array}{l}\text { Export performance } \\
\text { achievement improvement in } \\
\text { current period }\end{array}$ & 0.02 & -0.11 & 0.09 & 0.57 & 0.63 & 0.27 & 0.30 & 0.30 & 0.84 & \\
\hline & 10.- & $\begin{array}{l}\text { Satisfaction with export } \\
\text { performance improvement in } \\
\text { current period }\end{array}$ & -0.040 & -0.140 & -0.020 & 0.650 & 0.770 & 0.330 & 0.310 & 0.350 & 0.820 & 0.870 \\
\hline
\end{tabular}

Note: Diagonal: $\sqrt{A V E \xi_{j}} ;$ Fornell-Larcker criterion: $\sqrt{A V E \xi_{j}}>\max \left|\rho_{i j}\right| \forall_{i j}$

Table 3 Discriminant validity - heterotrait-monotrait correlations ratio 
Cite this article as: Malca, O., Peña-Vinces, J. \& Acedo, F. (2019) Export promotion programmes as export performance catalysts for SMEs: insights from an emerging economy. Small Bus Econ (2019).https://doi.org/10.1007/s11187-019-00185-2.

\begin{tabular}{|c|c|c|c|c|c|c|c|c|c|c|c|c|}
\hline & \multicolumn{3}{|c|}{ (A) } & \multicolumn{2}{|c|}{ (B) } & \multicolumn{3}{|c|}{ (C) } & \multicolumn{2}{|c|}{ (D) } \\
\hline & & & 1.- & 2.- & 3.- & 4.- & 5.- & 6.- & 7.- & 8.- & 9.- & 10.- \\
\hline \multirow{3}{*}{$\begin{array}{l}\text { (A) Export } \\
\text { promotion } \\
\text { programmes }\end{array}$} & 1.- & $\begin{array}{l}\text { Information-related } \\
\text { programmes }\end{array}$ & & & & & & & & & & \\
\hline & 2.- & $\begin{array}{l}\text { Education- and training- } \\
\text { related programmes }\end{array}$ & 0.89 & & & & & & & & & \\
\hline & 3.- & $\begin{array}{l}\text { Trade mobility-related } \\
\text { programmes }\end{array}$ & 0.71 & 0.76 & & & & & & & & \\
\hline \multirow{2}{*}{$\begin{array}{l}\text { (B) Preceding } \\
\text { year's exp. } \\
\text { performance }\end{array}$} & 4.- & $\begin{array}{l}\text { Performance achievement in } \\
\text { preceding year }\end{array}$ & 0.14 & 0.13 & 0.08 & & & & & & & \\
\hline & 5.- & $\begin{array}{l}\text { Satisfaction with preceding } \\
\text { year's performance }\end{array}$ & 0.11 & 0.12 & 0.09 & 0.85 & & & & & & \\
\hline \multirow{3}{*}{$\begin{array}{l}\text { (C) Export- } \\
\text { related } \\
\text { organisational } \\
\text { resources }\end{array}$} & 6.- & Managerial resources & 0.10 & 0.10 & 0.23 & 0.30 & 0.41 & & & & & \\
\hline & 7.- & $\begin{array}{l}\text { Production and research-and- } \\
\text { development }(R \& D) \text { resources }\end{array}$ & 0.13 & 0.18 & 0.06 & 0.36 & 0.46 & 0.89 & & & & \\
\hline & 8.- & Intellectual resources & 0.10 & 0.11 & 0.09 & 0.33 & 0.33 & 0.55 & 0.86 & & & \\
\hline \multirow{2}{*}{$\begin{array}{l}\text { (D) Current } \\
\text { export } \\
\text { performance } \\
\text { improvement }\end{array}$} & 9.- & $\begin{array}{l}\text { Export performance } \\
\text { achievement improvement in } \\
\text { current period }\end{array}$ & 0.08 & 0.14 & 0.11 & 0.63 & 0.70 & 0.31 & 0.39 & 0.35 & & \\
\hline & 10.- & $\begin{array}{l}\text { Satisfaction with export } \\
\text { performance improvement in } \\
\text { current period }\end{array}$ & 0.08 & 0.16 & 0.07 & 0.71 & 0.83 & 0.37 & 0.39 & 0.40 & 0.90 & \\
\hline
\end{tabular}

Note: Threshold: all HTMT ratios <HTMT(85) 
Cite this article as: Malca, O., Peña-Vinces, J. \& Acedo, F. (2019) Export promotion programmes as export performance catalysts for SMEs: insights from an emerging economy. Small Bus Econ (2019).https://doi.org/10.1007/s11187-019-00185-2.

Table 4 Discriminant validity - Partial cross-loadings criterion

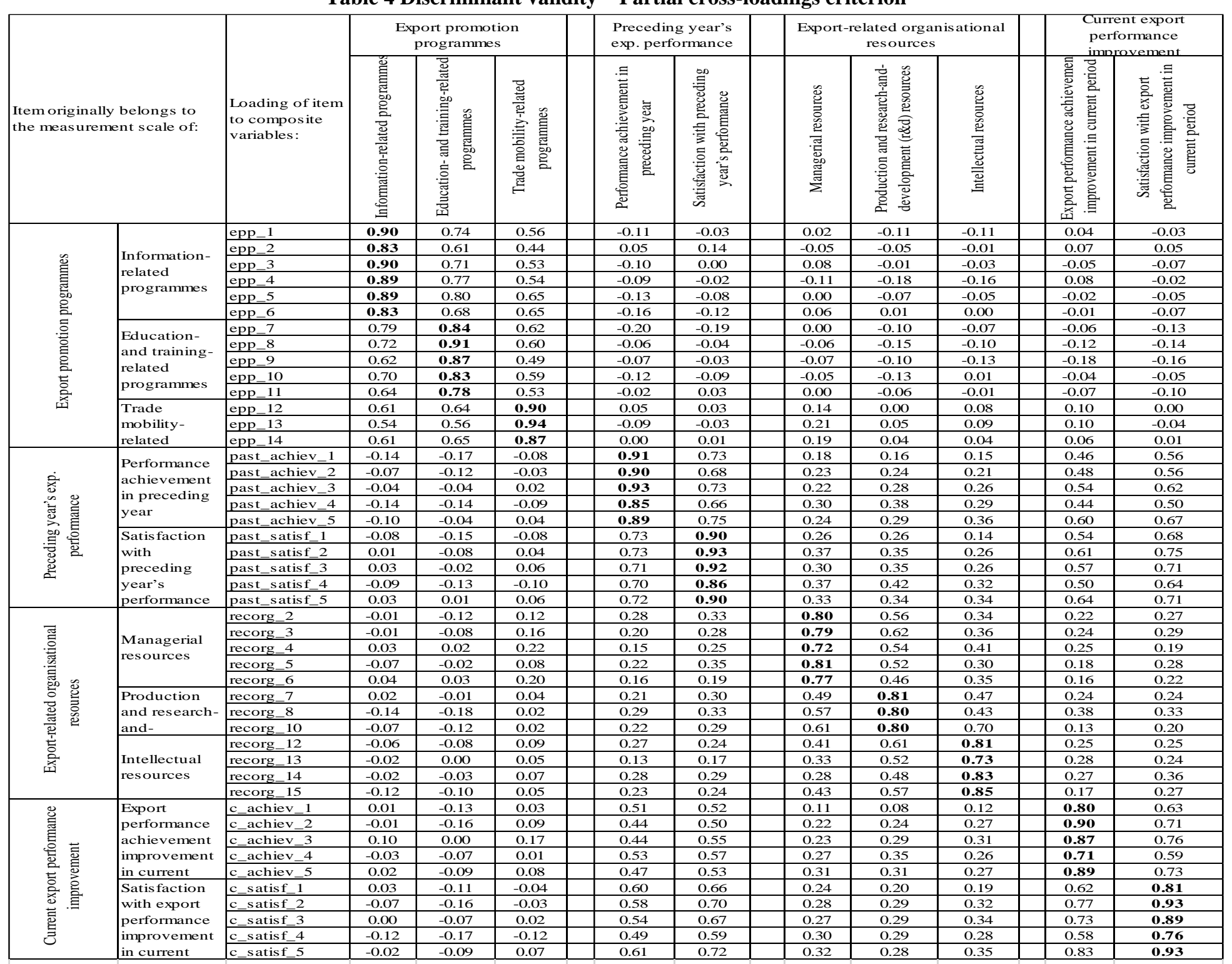


Cite this article as: Malca, O., Peña-Vinces, J. \& Acedo, F. (2019) Export promotion programmes as export performance catalysts for SMEs: insights from an emerging economy. Small Bus Econ (2019).https://doi.org/10.1007/s11187-019-00185-2.

Note: Highest partial cross-loading is highlighted in bold

Table 5 Structural model relationships, statistical significance, and hypothesis testing

\begin{tabular}{|c|c|c|c|c|c|c|c|}
\hline $\mathbf{N}^{\circ}$ & \multicolumn{3}{|c|}{ Structural model relationships } & $\boldsymbol{\beta}$ & t-value & Sig. & Supported \\
\hline \multicolumn{8}{|c|}{ Research hypotheses } \\
\hline H1 & $\begin{array}{l}\text { Information-, education-, and } \\
\text { training-related programmes }\end{array}$ & $\rightarrow$ & $\begin{array}{l}\text { Export-related organisational } \\
\text { resources }\end{array}$ & -0.262 & 1.902 & 0.057 & No \\
\hline $\mathrm{H} 2$ & $\begin{array}{l}\text { Trade mobility-related } \\
\text { programmes }\end{array}$ & $\rightarrow$ & $\begin{array}{l}\text { Export-related organisational } \\
\text { resources }\end{array}$ & 0.321 & 2.033 & 0.042 & Yes \\
\hline H3 & $\begin{array}{l}\text { Previous-year export } \\
\text { performance }\end{array}$ & $\rightarrow$ & $\begin{array}{l}\text { Export-related organisational } \\
\text { resources }\end{array}$ & 0.370 & 3.346 & 0.001 & Yes \\
\hline $\mathrm{H} 4$ & Previous export performance & $\rightarrow$ & $\begin{array}{l}\text { Current-period export } \\
\text { performance }\end{array}$ & 0.661 & 8.045 & 0.00 & Yes \\
\hline H5 & $\begin{array}{l}\text { Export-related organisational } \\
\text { resources }\end{array}$ & $\rightarrow$ & $\begin{array}{l}\text { Current-period export } \\
\text { performance (CPEP) }\end{array}$ & 0.131 & 1.511 & 0.131 & No \\
\hline \multicolumn{8}{|c|}{ Control variables } \\
\hline 1 & Number of workers & $\rightarrow$ & CPEP & 0.139 & 1.279 & 0.201 & NA \\
\hline 2 & Number of export markets & $\rightarrow$ & CPEP & 0.052 & 0.49 & 0.624 & NA \\
\hline 3 & Number of years exporting & $\rightarrow$ & CPEP & 0.107 & 1.065 & 0.287 & NA \\
\hline 4 & Sector (agribusiness) & $\rightarrow$ & CPEP & 0.023 & 0.299 & 0.764 & NA \\
\hline 5 & Export department & $\rightarrow$ & CPEP & -0.024 & 0.299 & 0.764 & NA \\
\hline
\end{tabular}

Fig. 2 PLS-SEM results - empirical model

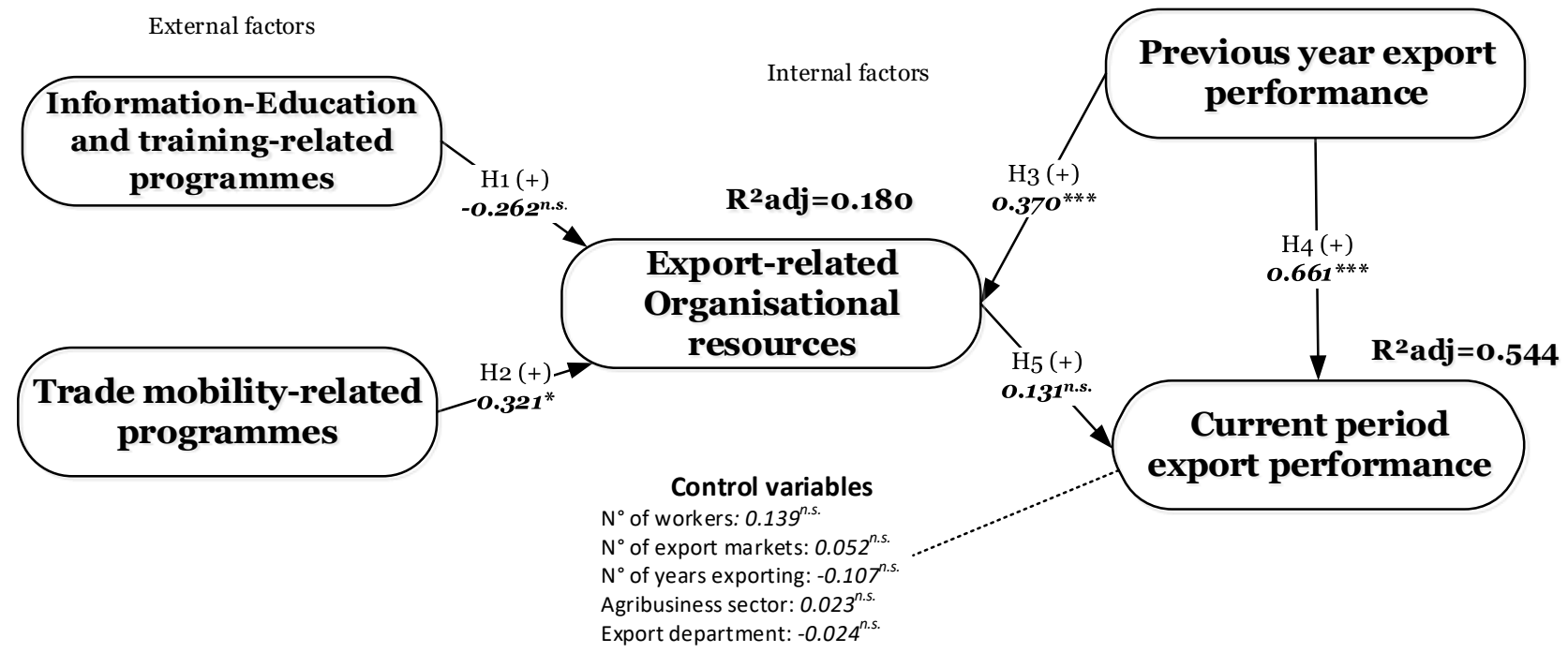

Note: * sig. $<0.05 ; * *$ sig. $<0.01 ; * * *$ sig. $<0.001 ;$ n.s.: not significant

\subsection{Robustness analyses}

To assess the robustness of the results, we searched for differences in the path coefficients based on the heterogeneity level of the sample (Hair et al. 2017). Accordingly, in order to uncover the number of homogeneous segments of exporting firms in the sample, the FIMIX-PLS procedure was employed (Sarstedt and Ringle 2010). Table 6 exhibits the selection of two exporting firms' segments given the highest value of the consistent Akaike information criterion (CAIC) and a value of 0.5 
Cite this article as: Malca, O., Peña-Vinces, J. \& Acedo, F. (2019) Export promotion programmes as export performance catalysts for SMEs: insights from an emerging economy. Small Bus Econ (2019).https://doi.org/10.1007/s11187-019-00185-2.

or higher of the normalised entropy statistic (EN) (Hair et al. 2016). Consequently, the study assessed measurement invariance in both segments before comparing the path coefficients (Henseler, Ringle and Sarstedt 2016). Table 7 shows that the composite variable of information-, education-, and training-related programmes fails to achieve compositional invariance. This result is attributable to the small segment size. Thus, total measurement invariance is held (Henseler, Ringle and Sarstedt 2016). Table 8 exhibits the results from the non-parametric path coefficient difference test (PLS-MGA). The test results fail to reject the hypothesis of path coefficient differences between the segments. Thus, the research results regarding the hypotheses tested and the control variables are consistent while including the heterogeneity level of the sample.

Table 6 FIMIX-PLS evaluation criteria and relative segment sizes

\begin{tabular}{|c|c|c|c|c|c|c|c|}
\hline \multirow{2}{*}{$\mathrm{S}$} & \multirow{2}{*}{$\begin{array}{l}\text { Modified Akaike's } \\
\text { information criterion } \\
\text { with factor } 3\left(\mathbf{A I C}_{3}\right)\end{array}$} & \multirow{2}{*}{$\begin{array}{l}\text { Bayesian } \\
\text { information } \\
\text { criterion } \\
\text { (BIC) }\end{array}$} & \multirow[t]{2}{*}{$\begin{array}{l}\text { Consistent } \\
\text { AIC (CAIC) }\end{array}$} & \multirow{2}{*}{$\begin{array}{c}\text { Normed } \\
\text { entropy } \\
\text { statistic }(\mathbf{E N})\end{array}$} & \multicolumn{3}{|c|}{ Relative segment sizes } \\
\hline & & & & & $\mathbf{S}=\mathbf{1}$ & $\mathbf{S}=\mathbf{2}$ & $\mathbf{S}=\mathbf{3}$ \\
\hline 1 & 1200.839 & 1247.455 & 1277.455 & - & $100 \%$ & & \\
\hline 2 & 1007.44 & 1102.226 & 1163.226 & 0.905 & $52.60 \%$ & $47.40 \%$ & \\
\hline 3 & 936.118 & 1079.074 & 1171.074 & 0.925 & $50.20 \%$ & $36.90 \%$ & $12.80 \%$ \\
\hline
\end{tabular}

Table 7 Measurement invariance assessment between FIMIX segments

\begin{tabular}{|c|c|c|c|}
\hline Composite & $\epsilon_{\left(s_{1}-s_{2}\right)} \quad$ value $(=1)$ & $\mathrm{Cl}_{95 \%}$ & Compositional invariance \\
\hline Previous-year export performance & 1.000 & {$[1.000 ; 1.000]$} & Yes $^{+}$ \\
\hline Current-period export performance & 0.999 & {$[0.999 ; 1.000]$} & Yes \\
\hline $\begin{array}{l}\text { Information-, education-, and training- } \\
\text { related programmes }\end{array}$ & 1.000 & {$[1.000 ; 1.000]$} & Yes \\
\hline Trade mobility-related programmes & 0.783 & {$[0.337 ; 1.000]$} & Yes \\
\hline Export-related organisational resources & 0.998 & {$[0.992 ; 1.000]$} & Yes \\
\hline Composite & $\xi_{s_{1}}-\xi_{s_{2}}$ & $\mathrm{CI}_{95 \%}$ & Equal means \\
\hline Previous-year export performance & 0.142 & {$[-0.401 ; 0.391]$} & Yes \\
\hline Current-period export performance & 0.404 & {$[-0.398 ; 0.399]$} & No \\
\hline $\begin{array}{l}\text { Information-, education-, and training- } \\
\text { related programmes }\end{array}$ & 0.132 & {$[-0.418 ; 0.410]$} & Yes \\
\hline Trade mobility-related programmes & 0.206 & {$[-0.404 ; 0.407]$} & Yes \\
\hline Export-related organisational resources & 0.003 & {$[-0.402 ; 0.392]$} & Yes \\
\hline Composite & $\log \left(\frac{\operatorname{var} \xi_{B_{1}}}{\operatorname{var} \xi_{a_{1}}}\right)$ & $\mathrm{Cl}_{95 \%}$ & Equal variances \\
\hline Previous-year export performance & 0.63 & {$[-0.675 ; 0.730]$} & Yes \\
\hline Current-period export performance & 0.101 & {$[-0.580 ; 0.582]$} & Yes \\
\hline $\begin{array}{l}\text { Information-, education-, and training- } \\
\text { related programmes }\end{array}$ & -0.253 & {$[-0.417 ; 0.437]$} & Yes \\
\hline Trade mobility-related programmes & -0.102 & {$[-0.338 ; 0.345]$} & Yes \\
\hline Export-related organisational resources & 0.684 & {$[-0.709 ; 0.740]$} & Yes \\
\hline
\end{tabular}

Note: + significant difference due to small segment size (Henseler, Ringle and Sarstedt 2016); confidence interval based on 5,000 permutations 
Cite this article as: Malca, O., Peña-Vinces, J. \& Acedo, F. (2019) Export promotion programmes as export performance catalysts for SMEs: insights from an emerging economy. Small Bus Econ (2019).https://doi.org/10.1007/s11187-019-00185-2.

Table 8 PLS-MGA: Path coefficient differences between segments

\begin{tabular}{|c|c|c|c|c|c|c|c|c|}
\hline & \multicolumn{3}{|c|}{ Segment $1(n=50)$} & \multicolumn{3}{|c|}{ Segment $2(n=45)$} & \multicolumn{2}{|c|}{ PLS-MGA } \\
\hline & $\beta_{g_{1}}$ & $\sigma_{s_{1}}$ & $\begin{array}{c}\text { t-value } \\
(\mathrm{sig})\end{array}$ & $\beta_{s_{2}}$ & $\sigma_{s_{2}}$ & $\begin{array}{c}\text { t-value } \\
(\mathrm{sig})\end{array}$ & $\Delta \beta_{s_{1}-s_{2}}$ & Sig. \\
\hline $\begin{array}{l}\text { H1: Information-, education-, and } \\
\text { training-related programmesà } \\
\text { export-related organisational }\end{array}$ & -0.344 & -0.128 & $\begin{array}{c}1.861 \\
(0.063)\end{array}$ & -0.128 & 0.184 & $\begin{array}{c}0.696 \\
(0.486)\end{array}$ & 0.215 & $0.797^{n . s .}$ \\
\hline $\begin{array}{l}\text { H2: Trade mobility-related } \\
\text { programmes à export-related } \\
\text { organis ational resources }\end{array}$ & 0.259 & 0.224 & $\begin{array}{c}1.155 \\
(0.248)\end{array}$ & 0.361 & 0.204 & $\begin{array}{c}1.771 \\
(0.077)\end{array}$ & 0.102 & $0.631^{n . s .}$ \\
\hline $\begin{array}{l}\text { H3: Previous-year export } \\
\text { performanceà export-related } \\
\text { organis ational resources }\end{array}$ & 0.261 & 0.165 & $\begin{array}{l}1.585 \\
(0.113\end{array}$ & 0.51 & 0.114 & $\begin{array}{c}4.459 \\
(0.000)\end{array}$ & 0.249 & $0.890^{n . s .}$ \\
\hline $\begin{array}{l}\text { H4: Previous-year export } \\
\text { performanceà current-period } \\
\text { export performance }\end{array}$ & 0.674 & 0.119 & $\begin{array}{c}5.663 \\
(0.000)\end{array}$ & 0.649 & 0.105 & $\begin{array}{c}6.166 \\
(0.000)\end{array}$ & 0.025 & $0.442^{n . s .}$ \\
\hline $\begin{array}{l}\text { H5: Export-related organis ational } \\
\text { resourcesà current-period export } \\
\text { performance }\end{array}$ & 0.119 & 0.119 & $\begin{array}{c}1.003 \\
(0.316)\end{array}$ & 0.173 & 0.127 & $\begin{array}{c}1.354 \\
(0.176)\end{array}$ & 0.054 & $0.612^{n . s .}$ \\
\hline
\end{tabular}

Note: $n . s .=$ no significant difference $($ two-tailed test $) ; * p<0.025$ o $p>0.975 ; * * p<0.005$ o $p>0.995 ; * * * p<0.0005$ o $p>0.9995$

\section{Discussion}

The main objective of this study was to explain the export performance of SMEs through the analysis of an empirical model concerning the external and internal factors of the firm (Madsen 1987; Wheeler et al. 2008). Accordingly, the study carried out a comparative analysis between the effect of an external factor, such as EPPs, and two internal variables, namely organisational resources and preceding-year export performance, on the SMEs' current export performance.

Analysing the effect of the firms' external factors on the internal factors, the study finds mixed effects of EPPs on the export-related organisational resources. Firstly, the study finds a positive and significant effect of EPPs' trade mobility programmes on export-related organisational resources of the exporting Peruvian SMEs. Specifically, trade mobility programmes exhibit a low influence on the development of specialised managerial skills in exporting, the allocation of a sufficient number of personnel to exporting, and the availability of unique production processes. Based on these results, Peruvian government agents in charge of the design of EPPs should characterise the SMEs' export-related resources level in order to account for the gap between these and the foreign market demand and contribute to their development in the long term. Additionally, trade mobility programmes should adjust their activities to the internationalisation stage and export market presence of the SMEs in order to promote a proactive approach to internationalisation, help decision-makers to overcome export-related mental barriers, and foster foreign market knowledge activities based on the SMEs' export stage. EPPs' trade mobility-related programmes enact the role of internationalisation catalyser when exporting firms hold a proactive orientation towards the export venture, expediting the information flow between the foreign market and the SME. 
Cite this article as: Malca, O., Peña-Vinces, J. \& Acedo, F. (2019) Export promotion programmes as export performance catalysts for SMEs: insights from an emerging economy. Small Bus Econ (2019).https://doi.org/10.1007/s11187-019-00185-2.

By contrast, the study finds that Peru's EPPs' information-, education-, and training-related programmes do not have a significant effect on export-related organisational resources. This result is consistent with previous findings (Leonidou, Palihawadana and Theodosiou 2011; Shamsuddoha, Yunus Ali and Ndubisi 2009), where it was found that information-, education-, and training-related programmes do not affect the internal characteristics of the exporting firms positively, since they take time to develop inside the organisation in comparison to trade mobility-related programmes, which exhibit a more immediate impact. Additionally, the organisational constraints that characterise developing countries' TPOs (Lederman, Olarreaga and Payton 2010), accounting for differences in firms' foreign market experience, export markets served, heterogeneity in manufacturing practices, and organisation- and product-specific attributes (Melitz and Redding 2014), may pose difficulties in the design of PPEs in this context. In consequence, EPPs should provide adequate information and training when firms pursue market penetration strategies in previously served export markets, and marketand product-specific information and training when expanding the export activity through diversification strategies. Despite the effect of EPPs' information-, education-, and training-related programmes, their impact and efficacy remain difficult to assess in the short run.

One of the reasons for the obtained results, in contrast with previous research studies, is that the results highlighted in this study demonstrate that the effect of the external variables of the firm, such as EPPs, will depend largely on the economy's institutional framework (Li, Vertinsky and Zhang 2013; Shirokova and Tsukanova 2013). Unlike large export markets that possess strong government bodies, emerging economies such as Peru possess weak institutions, and oftentimes they do not provide the appropriate resources to facilitate internationalisation of SMEs (Hessels and van Stel 2011; Li et al. 2013; Shirokova and Tsukanova 2013). Therefore, based on these findings, it can be concluded that there is a need to continue further research through evidence from emerging economies. Thus, the EPPs' effect is contingent and related to the economic environment of the firm.

Regarding the internal factors of the exporting Peruvian SMEs, results show that previous-year export performance positively influences the export-related resources of the firm and its current export performance. The evidence suggests that previous-year export performance weakly influences the development of resources related to knowledge about foreign business practices, a favourable managerial attitude towards exports, and the allocation of a sufficient number of personnel to exporting; however, it strongly affects the achievement and satisfaction level of current export performance. This result supports the idea that exporting SMEs do not commit additional resources to innovation, diversification, or export venture, and they rely on the reinforcement of successful past practices. Consequently, SMEs that pursue this behaviour and compete in low value-added industries, or rely on comparative advantages, may limit their international growth due to the lack of strategic resource development and competitive advantages.

Finally, this study finds evidence that export-related organisational resources do not have a significant effect on current export performance. Against the expected effect of the RBV (Hessels and van Stel 2011), our results entail that SMEs' export performance is not mainly driven by the possession of valuable, rare, and costly-to-imitate resources. SMEs that export comparative advantage-intensive products and low value-added and intermediate goods require a lower level of marketing adaptation and specialised resources. Consequently, SMEs rely on the definition of routines based on previously successful practices to support their international product and market development. This rationale may explain the sharp difference of significance and effect sizes between the impact of export-related organisational resources and previous-year 
Cite this article as: Malca, O., Peña-Vinces, J. \& Acedo, F. (2019) Export promotion programmes as export performance catalysts for SMEs: insights from an emerging economy. Small Bus Econ (2019).https://doi.org/10.1007/s11187-019-00185-2.

export performance on current export performance (Meyer, van Witteloostuijn and Beugelsdijk 2017). Therefore, exporting SMEs implement short-term-oriented routines and reduce the development and commitment of specialised export-related resources.

\subsection{Managerial implications}

The model implemented in this study contributes to the strategic decision-making process of the exporting SMEs by summarising the causal relationships that explain the export performance in the short run. The results show that the exporting Peruvian SMEs rely on past experiences and routines in order to attain their export performance level. This insight stresses the need to identify which resources and capabilities lead to proactive export strategies and the exploration of export market opportunities, given that exporters acquire foreign market knowledge mainly from past experiences. Consequently, feedback on the efficacy of various EPPs should be encouraged between export managers and policy-makers in order to contribute to their design and management.

Further, the mixed effect of EPPs on the organisational resources of SMEs may be caused by the lack of focus on the development of an international orientation, generation of foreign market knowledge, and identification of export business opportunities and market conditions, against what has been observed in other SMEs with a clear international orientation since inception (Oviatt and McDougall 2005). EPPs should enact the role of external resources in order to provide foreign market information, such as the competition level, business networks, and technological gap between market requirements and production capacity, and foster the identification and exploitation of export market opportunities and influence the internationalisation process. Accordingly, EPPs with this focus would assist the exporting SMEs' entrepreneurial objective to discover, enact, evaluate, and exploit international opportunities (Oviatt and McDougall 2005). To attain this objective, EPPs must consider the resources currently available to SMEs as well as their experience derived from their export portfolio.

The question is, is this the more adequate way of developing the international activity of firms? The nature of the activity in many of the developing countries with a low value-added orientation uses a reactive orientation towards internationalisation.

\subsection{Implications for institutions}

Based on the contribution of EPPs to the internal factors of exporting SMEs, policy-makers should assess their efficacy and foundations from both the international trade economic theory and the internationalisation theory of SMEs (Lu and Beamish 2001). Consequently, the design of the EPPs should address the creation of trade through the development of capabilities that reduce the psychic distance faced by SMEs in foreign markets in order to improve the ability to identify, evaluate, and exploit opportunities (Oviatt and McDougall 2005; Stöttinger and Schlegelmilch 1998). The development of such capabilities could be prioritised following the internationalisation process model, given the incipient intra-regional trade vs high extra-regional trade in the Peruvian export scenario (Malca 2016). 
Cite this article as: Malca, O., Peña-Vinces, J. \& Acedo, F. (2019) Export promotion programmes as export performance catalysts for SMEs: insights from an emerging economy. Small Bus Econ (2019).https://doi.org/10.1007/s11187-019-00185-2.

Finally, the design of EPPs in emerging economies such as Peru should deemphasise the focus on the market access-related assistance and reinforce the development of the capabilities required to access niche markets, given the rise of the world middle class (ITC 2014). In this sense, policy-makers responsible for the design of EPPs should include programmes aimed at the development of export-oriented resources and capabilities, along with market access assistance. In this sense, EPPs' agents should identify firm-level gaps between the resource base of the SMEs and the required resources and capabilities to compete in foreign markets due to the current reliance on comparative advantage-based exports. Hence, EPPs that account for foreign market requirements and restrictions hold a secondary role in meeting the need to design EPPs that strengthen the export-related resources and capabilities of SMEs, which are transversal to industries, products, and markets served.

\section{Conclusion}

This paper analysed the effect of EPPs on the international-related resources of the firms and how these, in turn, affect the export performance in an emerging economy. In this situation, the firms rely more on their previous experience and results than on a strategic orientation.

The role of EPPs is related to the resources devoted to international activity, but these are not fully determinant of their international performance. The lack of effect found in the formative role may explain this situation. The firms in developing countries and emerging economies are more customer-oriented and reactive than any other. The particular case of Peru with a strong predominance of exports from low value-added industries may also be an example to other economies with similar dependence.

When firms have positive results, they believe that education and formation are not necessary, and they incorporate resources as the government supports them. Results seem to indicate that these resources are not fully incorporated in the internationalisation process and therefore do not contribute to increasing the international performance of the firm.

\section{$7 \quad$ Limitations and future research directions}

The results provided in the present study should be interpreted regarding the characteristics of the Peruvian export industry. Additionally, the study disregards time-dependent effects of information-, education-, and training-related programmes due to the cross-sectional research design. The study acknowledges that several external and internal variables that may be relevant determinants of export performance are not included in the study, such as the interaction of free trade agreements and the impact of dynamic capabilities, respectively (Teece and Pisano 1994; Wilden, Gudergan, Nielsen and Lings 2013). Future studies should contribute to the literature through evidence from emerging economies, such as the LA case, and consider the long-term effects of EPPs on the development of export-related resources in SMEs. These studies will contribute to the debate on both external and internal determinants of export performance through research methods that consider the multidimensional nature of the topic (Chen, Sousa and He 2016). 
Cite this article as: Malca, O., Peña-Vinces, J. \& Acedo, F. (2019) Export promotion programmes as export performance catalysts for SMEs: insights from an emerging economy. Small Bus Econ (2019).https://doi.org/10.1007/s11187-019-00185-2.

Further, given the significance of trade mobility-related programmes in SMEs' experiential knowledge and resource development, future studies may address their influence on the efficacy of the export venture in current or new foreign markets. The results of the study highlight the idea that SMEs' market knowledge is driven by trade mobility-related programmes and previous export performance outcomes. Future studies should address the interaction of the absorptive capacity between the use of EPPs and the internal factors, as well as the possible mediation effect of EPPs on the organisational learning capabilities of the SME (Cavusgil and Zou 1994).

\section{$8 \quad$ References}

Aaby, N., Slater, S. (1989). Management influences on export performance: a review of the empirical literature 19781988. International Marketing Review, 6(4), 7-26.

Acedo, F., Barroso, C. \& Galan, J. (2006). The resource-based theory: dissemination and main trends. Strategic Management Journal, 27(7), 621-636.

Agencia de Promoción de la Inversión Privada - Perú - PROINVERSION. (2013). LEY N³0056 LEY QUE MODIFICA DIVERSAS LEYES PARA FACILITAR LA INVERSIÓN, IMPULSAR EL DESARROLLO PRODUCTIVO Y EL CRECIMIENTO EMPRESARIAL. https://www.proinversion.gob.pe/RepositorioAPS/1/0/arc/LAW_30056/Ley\%20N\%2030056.pdf Accessed 20 January 2016.

Andersen, O. (1993). On the internationalization process of firms: a critical analysis. Journal of International Business Studies, 24(2), 209-231.

Barney, J. (1991). Firm resources and sustained competitive advantage. Journal of Management, 17(1), 99-120.

Bloomberg (2018). These are 2018's most (and least) attractive emerging markets. https://www.bloomberg.com/news/articles/2018-01-21/emerging-market-scorecard-supports-mexico-andturkey-over-india. Accessed 24 August 2018.

Broocks, A., \& van Biesebroeck, J. (2017). The impact of export promotion on export market entry. Journal of International Economics, 107(July), 19-33.

Buckley, P. J., Pass, C. L. \& Prescott, K. (1990). Measures of international competitiveness: empirical findings from British manufacturing companies. Journal of Marketing Management, 6(1), 1-13.

Calderón, H., \& Fayos, T. (2004). Análisis de la relación entre el compromiso exportador y las ayudas a la internacionalización de las empresas. Investigaciones Europeas de Dirección y Economía de la Empresa, 10(2), 201-220.

Castro-Gonzáles, S., Peña-Vinces, J. C. \& Guillen, J. (2016). The competitiveness of Latin-American economies: consolidation of the double-diamond theory. Economic System, 4(10), 73-386.

Cavusgil, S. T. \& Zou, S. (1994). Marketing strategy-performance relationship: an investigation of the empirical link in export market ventures. Journal of Marketing, 58(1), 1-21.

Chang, S.-J., van Witteloostuijn, A. \& Eden, L. (2010). From the Editors: Common method variance in international business research. Journal of International Business Studies, 41(2), 178-184.

Chen, J., Sousa, C. M., \& He, X. (2016). The determinants of export performance: a review of the literature 2006-2014. International Marketing Review, 33(5), 626-670.

Conner, K. R. \& Prahalad, C. K. (1996). A resource-based view of the firm: knowledge vs. opportunism. Organization Science, 7(5), 477-501.

Coughlin, C. \& Cartwright, P. (1987). An examination of state foreign export and manufacturing employment. Economic Development Quarterly, 1(3), 257-267.

Cyert, R., \& March, J. (1992). A behavioral theory of the firm. Malden, Massachusetts: Blackwell Business.

Dhanaraj, C. \& Beamish, P. (2003). A resource-based approach to the study of export performance. Journal of Small Business Management, 41(3), 242-261.

Doty, D. H. \& Glick, W. H. (1998). Common methods bias: Does common methods variance really bias results? Organizational Research Methods, 1(4), 374-406.

European Commission. (2005). The new SME definition: User guide and model declaration. European Commission: Enterprise and Industry Publications. 
Cite this article as: Malca, O., Peña-Vinces, J. \& Acedo, F. (2019) Export promotion programmes as export performance catalysts for SMEs: insights from an emerging economy. Small Bus Econ (2019).https://doi.org/10.1007/s11187-019-00185-2.

Faroque, A. R. \& Takahashi, Y. (2015). Export marketing assistance and early internationalizing firm performance: Does export commitment matter? Asia Pacific Journal of Marketing and Logistics, 27(3), 421-443.

Fischer, E. \& Reuber, A. R. (2003). Targeting export support to SMEs: Owners' international experience as a segmentation basis. Small Business Economics, 20(1), 69-82.

Francis, J. \& Collins-Dodd, C. (2004). Impact of export promotion programs on firm competencies, strategies and performance: The case of Canadian high-technology SMEs. International Marketing Review, 21(4/5), 474-495.

Freixanet, J. (2010). La Evaluación del Impacto de los Programas de Promoción de la Internacionalización. Una Aplicación al Caso de las Empresas de Cataluña. Tribuna de Economía ICE, 854(May-June), 105-121.

Freixanet, J. (2012). Export promotion programs: Their impact on companies' internationalization performance and competitiveness. International Business Review, 21(6), 1065-1086.

Gençtürk, E. \& Kotabe, M. (2001). The effect of export assistance program usage on export performance: a contingency explanation. Journal of International Marketing, 9(2), 51-72.

Gillespie, K. \& Riddle, L. (2004). Export promotion organization emergence and development: a call to research. International Marketing Review, 21(4/5), 462-473.

Greeve, H. R. (1998). Performance, aspirations, and risky organizational change. Administrative Science Quarterly, 43(1), 58-86.

Haddoud, M. Y., Jones, P. \& Newbery, R. (2017). Export promotion programmes and SMEs' performance. Journal of Small Business and Enterprise Development, 24(1), 68-87.

Hair, J. F., Black, W. C., Babin, B. J. \& Anderson, R. E. (2014). Multivariate data analysis. Essex: Pearson Education.

Hair, J. F., Ringle, C. M. \& Sarstedt, M. (2013). Partial least squares structural equation modeling: rigorous applications, better results and higher acceptance. Long Range Planning, 46(1/2), 1-12.

Hair, J. F., Sarstedt, M., Matthews, L. \& Ringle, C. M. (2016). Identifying and treating unobserved heterogeneity with FIMIX-PLS: Part I - Method. European Business Review, 28(1), 63-78.

Hair, J. F., Sarstedt, M., Ringle, C. M., \& Gudergan, S. P. (2017). Advanced issues in partial least squares structural equation modeling. California: SAGE Publications.

Harzing, A.-W. (1997). Response rates in the international mail surveys: results of a 22-country study. International Business Review, 6(6), 641-665.

Harzing, A.-W., Reiche, S. \& Pudelko, M. (2013). Challenges in International Survey Research: A review with illustrations and suggested solutions for best practice. European Journal of International Management, 7(1), $112-134$.

Helfat, C. (1994). Firm-specificity in corporate applied R\&D. Organization Science, 5(2), 173-184.

Henseler, J., Ringle, C. M., \& Sarstedt, M. (2016). Testing measurement invariance of composites using partial least squares. International Marketing Review, 33(3), 405-431.

Hessels, J. \& van Stel, A. (2011). Entrepreneurship, export orientation, and economic growth. Small Business Economics, $37(2), 255-268$.

Hult, G., Ketchen, D., Griffith, D., et al. (2008). An assessment of the measurement of performance in international business research. Journal of International Business Studies, 39(6), 1064-1080.

Hult, G. T. M., Ketchen, D. J., Griffith, D. A., Chabowski, B. R., Hamman, M. K., Dykes, B. J. \& Cavusgil, S. T. (2008). An assessment of the measurement of performance in international business research. Journal of International Business Studies, 39(6), 1064-1080.

Hultman, M., Katsikeas, C. S. \& Robson, M. J. (2011). Export promotion strategy and performance: the role of international experience. Journal of International Marketing, 19(4), 17-39.

ITC. (2014). From export promotion to internationalization: the role of trade promotion organizations in the evolving global economy. Dubai: TPO Network World Conference \& Awards. Accessed 20 January 2016.

Johanson, J. \& Vahlne, J. (1977). The internationalization process of the firm: a model of knowledge development and increasing foreign market commitments. Journal of International Business Studies, 8(1), 23-32.

Jöreskog, K. \& Wold, H. (1982). Systems under indirect observation: causality, structure, prediction (Vol. 139). NorthHolland Publ. Amsterdam; New York.

Kaleka, A. (2002). Resources and capabilities driving competitive advantage in export markets: guidelines for industrial exporters. Industrial Marketing Management, 31(3), 273-283.

Katsikeas, C. S., Piercy, N. F. \& Ioannidis, C. (1996). Determinants of export performance in an European context. European Journal of Marketing, 30(6), 6-35. 
Cite this article as: Malca, O., Peña-Vinces, J. \& Acedo, F. (2019) Export promotion programmes as export performance catalysts for SMEs: insights from an emerging economy. Small Bus Econ (2019).https://doi.org/10.1007/s11187-019-00185-2.

Kotabe, M. \& Czinkota, M. (1992). State government promotion of manufacturing exports: a gap analysis. Journal of International Business Studies, 23(4), 637-658.

Lages, L. F., Jap, S. \& Griffith, D. (2008). The role of past performance in export ventures: a short-term reactive approach. Journal of International Business Studies, 39(2), 304-325.

Lages, L. F. \& Montgomery, D. (2005). The relationship between export assistance and performance improvement in Portuguese export ventures: an empirical test of the mediating role of pricing strategy adaptation. European Journal of Marketing, 39(7-8), 755-784.

Lant, T. K. (1992). Aspiration level adaptation: an empirical exploration. Management Science, 38(5), 623-644.

Lant, T. K., Mezias, S. J. (1992). An organizational learning model of convergence and reorientation. Organization Science, 3(1), 47-71.

Lant, T. K., Milliken, F. J., Batra, B. (1992). The role of managerial learning and interpretation in strategic persistence and reorientation: an empirical exploration. Strategic Management Journal, 15(6), 503-517.

Lederman, D., Olarreaga, M., Payton, L. (2010). Export promotion agencies: do they work? Journal of Development Economics, 91(2), 257-265.

Leonidou, L., Katsikeas, C., Coudounaris, D. (2010). Five decades of business research into exporting: A bibliographic analysis. Journal of International Management, 16(1), 78-91.

Leonidou, L., Katsikeas, C., Piercy, N. (1998). Identifying managerial influences on exporting: past research and future directions. Journal of International Marketing, 6(2), 74-102.

Leonidou, L., Katsikeas, C., Samiee, S. (2002). Marketing strategy determinants of export performance: a meta-analysis. Journal of Business Research, 55(1), 51-67.

Leonidou, L., Palihawadana, D., Theodosiou, M. (2011). National export-promotion programs as drivers of organizational resources and capabilities: effects on strategy, competitive advantage, and performance. Journal of International Marketing, 19(2), 1-29.

Levinthal, D., March, J. (1993). The myopia of learning. Strategic Management Journal, 14(S2), 95-112.

Levitt, B., March, J. G. (1988). Organizational learning. American Review of Sociology, 14, 319-340.

Li, J., Vertinsky, I. \& Zhang, H. (2013). The quality of domestic legal institutions and export performance. Management International Review, 53(3), 361-390.

Lim, J.-S., Sharkey, T. W. \& Kim, K. I. (1996). Competitive environmental scanning and export involvement: An initial inquiry. International Marketing Review, 13(1), 65-80.

Losada-Pérez, F., Ruzo-Sanmartín, E., Barreiro-Fernández, J. M. \& Navarro-García, A. (2007). Influencia de la estrategia de expansión internacional y de las características empresariales sobre el resultado exportador de la empresa. Revista ICE-Información Comercial Española, 837(July-August), 255-272.

Lu, J. W. \& Beamish, P. W. (2001). The internationalization and performance of SMEs. Strategic Management Journal, 22(6/7), 565-586.

Luo, Y. \& Peng, M. (1999). Learning to compete in a transition economy: experience, environment, and performance. Journal of International Business Studies, 30(2), 269-295.

Madsen, T. K. (1987). Empirical export performance studies: a review of conceptualizations and findings. In S. T. Cavusgil, Advances in international marketing (Vol. 2, pp. 177-198). Greenwich, CT: JAI Press.

Madsen, T. K. (1989). Successful export marketing management: some empirical evidence. International Marketing Review, 6(4), 41-57.

Malca, O. (2016). La internacionalización de las empresas desde el enfoque gradualista de Uppsala y de la integración económica: el caso de las exportaciones de confecciones peruanas en los mercados de la Alianza del Pacífico y del Mercosur. In M. de Miranda Parrondo, J. T. Pelaez Soto, Las relaciones económicas entre América Latina y Asia. Hacia la construcción de una nueva inserción internacional (pp. 239-290). Santiago de Cali: Pontificia Universidad Javeriana.

March, J. \& Sutton, R. (1997). Crossroads-organizational performance as dependent variable. Organization Science, $8(6), 698-706$.

Melitz, M. J. \& Redding, S. J. (2014). Heterogeneous firms and trade. In G. Gopinath, E. Helpman, K. Rogoff, Handbook of international economics (pp. 1-54). Oxford: North-Holland Elsevier.

Meyer, K., van Witteloostuijn, A. \& Beugelsdijk, S. (2017). What's in a p? Reassessing best practices for conducting and reporting hypothesis-testing research. Journal of International Business Studies, 48(5), 535-551. 
Cite this article as: Malca, O., Peña-Vinces, J. \& Acedo, F. (2019) Export promotion programmes as export performance catalysts for SMEs: insights from an emerging economy. Small Bus Econ (2019).https://doi.org/10.1007/s11187-019-00185-2.

Morgan, N., Vorhies, D. \& Schlegelmilch, B. (2006). Resource-performance relationships in industrial export ventures: the role of resource inimitability and substitutability. Industrial Marketing Management, 35(5), 621-633.

Nalcacia, G. \& Yagcib, M. (2014). The effects of marketing capabilities on export performance using resource-based view: assessment on manufacturing companies. Procedia - Social and Behavioral Sciences, 148, 671-679.

Navarro, A., Acedo, F., Losada, F. \& Ruzo, E. (2011). Integrated model of export activity: analysis of heterogeneity in managers' orientations and perceptions on strategic management in foreign markets. Journal of Marketing Theory and Practice, 19(2), 187-204.

Oviatt, B. M. \& McDougall, P. P. (1997). Challenges for internationalization process theory: the case of international new ventures. Management International Review, 37(2), 85-99.

Oviatt, B. M. \& McDougall, P. P. (2005). Defining international entrepreneurship and modeling the speed of internationalization. Entrepreneurship Theory \& Practice, 29(5), 537-553.

Paul, J. \& Dikova, D. (2016). The internationalization of Asian firms: an overview and research agenda. Journal of EastWest Business, 22(4), 237-241.

Paul, J. \& Gupta, P. (2014). Process and intensity of internationalization of IT firms: Evidence from India. International Business Review, 23(3), 594-603.

Paul, J., Parthasarathy, S. \& Gupta, P. (2017). Exporting challenges of SMEs: A review and future research agenda. Journal of World Business, 52(3), 327-342.

Peña-Vinces, J. C., Casanova, L., Guillen, J. \& Urbano, D. (2017). International competitiveness of small and mediumsized enterprises: Peru, a Latin-American emerging market. Emerging Markets Finance and Trade, 53(1), 150169.

Penrose, E. (1959). The growth of the firm (1st ed.). New York: Oxford University Press.

Piercy, N., Kaleka, A. \& Katsikeas, C. (1998). Sources of competitive advantage in high performing exporting companies. Journal of World Business, 33(4), 378-393.

Podsakoff, P. M., MacKenzie, S. B., Lee, J. Y. \& Podsakoff, N. P. (2003). Common method biases in behavioral research: A critical review of the literature and recommended remedies. Journal of Applied Psychology, 88(5), 879-903.

Reinartz, W., Haenlein, M. \& Henseler, J. (2009). An empirical comparison of the efficacy of covariance-based and variance-based SEM. International Journal of Research in Marketing, 26(4), 332-344.

Ringle, C. M., Wende, S. \& Becker, J.-M. (2015). SmartPLS 3. Bönningstedt: SmartPLS.

Ruppenthal, T. \& Bausch, A. (2009). Research on export performance over the past 10 years: a narrative review. European Journal of International Management, 3(3), 328-364.

Sarstedt, M., Hair, J. F., Ringle, C. M., Thiele, K. O. \& Gudergan, S. P. (2016). Estimation issues with PLS and CBSEM: Where the bias lies!. Journal of Business Research, 69(10), 3998-4010.

Sarstedt, M. \& Ringle, C. (2010). Treating unobserved heterogeneity in PLS path modeling: a comparison of FIMIX-PLS with different data analysis strategies. Journal of Applied Statistics, 37(8), 1299-1318.

Seringhaus, F. H. \& Botschen, G. (1991). Cross-national comparison of export promotion services: the views of Canadian and Austrian. Journal of International Business Studies, 22(1), 115-133.

Seringhaus F.H. \& Rosson P.J. (1991) Export promotion and public organizations: State-of-the-art. In: Seringhaus F.H.R., Rosson P.J. (eds) Export Development and Promotion: The Role of Public Organizations. Springer, Boston, MA.

Seringhaus, F. H. \& Rosson, P. J. (1998). Management and performance of international trade fair exhibitors: government stands vs independent stands. International Marketing Review, 15(5), 398-412.

Shamsuddoha, A. K., Yunus Ali, M. \& Ndubisi, N. O. (2009). Impact of government export assistance on internationalization of SMEs from developing nations. Journal of Enterprise Information Management, 22(4), 408-422.

Shirokova, G. \& Tsukanova, T. (2013). Internationalization of SMEs from transition economies: institutional perspectives. In H. Etemad, T. K. Madsen, E. S. Rasmussen, P. Servais, Current issues in international entrepreneurship (pp. 174-198). Cheltenham, UK.

Singer, T. \& Czinkota, M. (1994). Factors associated with effective use of export assistance. Journal of International Marketing, 22(4), 53-71. 
Cite this article as: Malca, O., Peña-Vinces, J. \& Acedo, F. (2019) Export promotion programmes as export performance catalysts for SMEs: insights from an emerging economy. Small Bus Econ (2019).https://doi.org/10.1007/s11187-019-00185-2.

Sousa, C. M., Martínez-López, F. J. \& Coelho, F. (2008). The determinants of export performance: A review of the research in the literature between 1998 and 2005. International Journal of Management Reviews, 10(4), 343374.

Spence, M. M. (2003). Evaluating export promotion programmes: U.K. overseas trade missions and export performance. Small Business Economics, 20(1), 83-103.

Stöttinger, B. \& Schlegelmilch, B. B. (1998). Explaining export development through psychic distance: enlightening or elusive? International Marketing Review, 15(5), 357-372.

Teece, D. \& Pisano, G. (1994). The dynamic capabilities of firms: an introduction. Industrial and Corporate Change, $3(3), 537-556$.

The World Bank. (2018). The World Bank, indicators: Data bank microdata data catalog. http://data.worldbank.org/indicator. Accessed 24 August 2018.

Van Biesebroeck, J., Yu, E. \& Chen, S. (2015). The impact of trade promotion services on Canadian exporter performance. Canadian Journal of Economics / Revue canadienne d'economique, 48(4), 1481-1512.

Wang, X., Chen, A., Wang, H. \& Li, S. (2017). Effect of export promotion programs on export performance: evidence from manufacturing SMEs. Journal of Business Economics and Management, 18(1), 131-145.

Weaver, K., Berkowitz, D. \& Davies, L. (1998). Increasing the efficiency of national export promotion programs: The case of Norwegian exporters. Journal of Small Business Management, 36(4), 1-11.

Wernerfelt, B. (1984). A resource-based view of the firm. Strategic Management Journal, 5(2), 171-180.

Wheeler, C., Ibeh, K. \& Dimitratos, P. (2008). UK export performance research: review and implications. International Small Business Journal, 26(2), 207-239.

Wilden, R., Gudergan, S., Nielsen, B. \& Lings, I. (2013). Dynamic capabilities and performance: strategy, structure and environment. Long Range Planning, 46(1), 72-96.

Wilkinson, T. \& Brouthers, L. (2000). An evaluation of the state sponsored promotion programs. Journal of Business Research, 47(3), 229-236.

Zou, S. \& Stan, S. (1998). The determinants of export performance: a review of the empirical literature between 1987 and 1997. International Marketing Review, 15(5), 333-356. 
Cite this article as: Malca, O., Peña-Vinces, J. \& Acedo, F. (2019) Export promotion programmes as export performance catalysts for SMEs: insights from an emerging economy. Small Bus Econ (2019).https://doi.org/10.1007/s11187-019-00185-2.

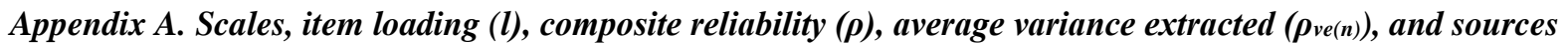

I. Type of Export Promotion Programme (Leonidou, Palihawadana and Theodosiou, 2011)

Question Regarding the use of EPPs, how much do you approve/disapprove of the utility of the programmes that the firm has adopted? Scale: 1=totally disapprove; 7=totally approve.

Information-, Education-, and Training-Related Programmes (second-order composite variable; $\rho=0.96 ; \rho_{v e(n)=0.68)}$

Information-Related Programmes (first-order composite variable; $\rho=0.95 ; \rho_{\text {ve }(n)}=0.76$ )

a. Information about foreign market opportunities $(l=0.90)$

b. Specific information about doing business with a particular firm $(l=0.83)$

c. General information about doing business in a specific country $(l=0.90)$

d. Provision of marketing information/advice $(l=0.89)$

e. General literature on how to export $(l=0.89)$

f. Export publications $(l=0.83)$

Education- and Training-Related Programmes (first-order composite variable; $\rho=0.93 ; \rho_{\text {ve }(n)}=0.72$ )

a. Organisation of export seminars/conferences $(l=0.83)$

b. Training programmes specialising in exporting $(l=0.78)$

c. Training on export documentation $(l=0.84)$

d. Provision of counselling advice on export business $(l=0.92)$

e. Foreign language support $(l=0.87)$

Trade Mobility-Related Programmes (first-order composite variable; $\rho=0.93 ; \rho_{\text {ve }(n)}=0.82$ )

a. Assistance in participating in trade shows/exhibitions $(l=0.90)$

b. Participation in trade missions in foreign markets $(l=0.94)$

c. Support by trade offices abroad $(l=0.87)$

II. Export-Related Organisational Resources (Kaleka, 2002; Leonidou, Palihawadana and Theodosiou, 2011)

Question Based on the export-related organisational resources of the firm, how would you rate the change in the following resources between the current and the previous year? Scale: 1=decreased significantly; 7=increased significantly.

Export-Related Organisational Resources (second-order composite variable; $\rho=0.91 ; \rho_{\text {ve }(n)}=0.46$ )

Managerial resources (first-order composite variable; $\rho=0.88 ; \rho_{\text {ve }(n)}=0.60$ )

a. Specialised managerial skills/competence in exporting $(l=0.80)$

b. Management experience/exposure in foreign markets $(l=0.79)$

c. Favourable managerial attitude towards exports $(l=0.72)$

d. Allocation of sufficient number of personnel to exporting $(l=0.81)$

e. Personnel specially trained in export activities $(l=0.77)$

Production and research-and-development $(\mathbf{R} \& D)$ resources (first-order composite variable; $\left.\rho=0.84 ; \rho_{\text {ve }(n)}=0.64\right)$

a. Modern production technology and equipment for exporting $(l=0.80)$

b. Availability of production capacity for exports $(l=0.81)$

c. Possession of proprietary technical knowledge for exports $(l=0.80)$

Intellectual resources (first-order composite variable; $\rho=0.88 ; \rho_{v e(n)}=0.65$ )

a. Knowledge about foreign market demand $(l=0.81)$ 
Cite this article as: Malca, O., Peña-Vinces, J. \& Acedo, F. (2019) Export promotion programmes as export performance catalysts for SMEs: insights from an emerging economy. Small Bus Econ

(2019).https://doi.org/10.1007/s11187-019-00185-2.

b. Knowledge about foreign business practices $(l=0.73)$

c. Knowledge about export regulations and paperwork $(l=0.83)$

d. Knowledge about export logistical requirements $(l=0.85)$

III. Preceding Year's Export Performance (Lages, Jap and Griffith, 2008)

Preceding Year's Export Performance (second-order composite variable; $\rho=0.96 ; \rho_{\text {ve }(n)}=0.73$ )

Performance Achievement in Preceding Year (first-order composite variable; $\rho=0.95 ; \rho_{v e(n)}=0.80$ )

Question How well did your company achieve the following objectives for the main export venture in the preceding year? Scale 1=very badly; $7=$ very well.

a. Export sales volume $(l=0.91)$

b. Export sales revenue $(l=0.90)$

c. Export profitability $(l=0.93)$

d. Market share in the main importing market $(l=0.85)$

e. Overall export performance $(l=0.89)$

Satisfaction with preceding year's performance (first-order composite variable; $\rho=0.96 ; \rho_{\text {ve }(n)}=0.82$ )

Question How satisfied are you with the current year's results of your main export venture? Scale: 1=not satisfied at all; $7=$ extremely satisfied.

a. Export sales volume $(l=0.90)$

b. Export sales revenue $(l=0.93)$

c. Export profitability $(l=0.92)$

d. Market share in the main importing market $(l=0.86)$

e. Overall export performance $(l=0.90)$

IV. Current Export Performance Improvement (Lages, Jap and Griffith, 2008)

Current Export Performance Improvement (second-order composite variable; $\rho=0.95 ; \rho_{v e(n)}=0.66$ )

Export Performance Achievement Improvement in Current Period (first-order composite variable; $\rho=0.92$; $\left.\rho_{v e(n)}=0.70\right)$

Question How well did your company achieve the following objectives for the main export venture in the current period? Scale $1=$ very badly; $7=$ very well.

a. Export sales volume $(l=0.80)$

b. Export sales revenue $(l=0.91)$

c. Export profitability $(l=0.87)$

d. Market share in the main importing market $(l=0.71)$

e. Overall export performance $(l=0.89)$

Satisfaction with Export Performance Improvement in Current Period (first-order composite variable; $\rho: 0.94 ; \rho_{v e(n)}$ : $0.75)$

Question How satisfied are you with the current period's results of your main export venture? Scale: 1=not satisfied at all; $7=$ extremely satisfied.
a. Export sales volume $(l=0.81)$
b. Export sales revenue $(l=0.93)$
c. Export profitability $(l=0.89)$
d. Market share in the main importing market $(l=0.76)$
e. Overall export performance $(l=0.93)$ 